\title{
Conjugated Polymer Gels with Dendritic Hydrophilic Side Chains
}

\author{
By Naoya ADACHI, ${ }^{1}$ Yoko TATEWAKI, ${ }^{2}$ Hirofusa SHIRAI, ${ }^{2}$ and Mutsumi KIMURA ${ }^{1,2, *}$
}

This paper reports the synthesis and optical properties of poly( $p$-phenylene ethynylene) gels that features hydrophilic dendritic groups. The conjugated polymer gel particles with hydrophilic side chains have been prepared by a synthetic route that involves initial preparation of an analogue polymer gel having triester side chains through the modified Pd-catalyzed Sonogashira cross-coupling reaction in aqueous emulsion, and the following conversion of ester groups with tris(hydroxymethyl)aminomethane (Tris). The size distribution of the water-swollen particles is relatively narrow with an average diameter of $900 \mathrm{~nm}$. The synthesized particles showed fluorescence and volume changes in response to various solvent compositions.

KEY WORDS: Poly( $p$-phenylene ethynylene)s / Hydrophilic Conjugated Polymers / Conjugated Polymer Gels / Volume Change /

Fluorescence Change /

Water-soluble conjugated polymers with hydrophilic side chains have been the subject of much interest due to their abilities in trace detection of analytes such as ions, peptides, proteins and nucleic acids in an aqueous environment. ${ }^{1-5}$ To achieve high solubility in water, sulfonic, ${ }^{2}$ carboxylic, ${ }^{3}$ ammonium $^{4}$ or oligo(ethylene glycol) ${ }^{5}$ groups have been introduced into the side chains of various conjugated polymers. However, water-soluble conjugated polymers tend to aggregate through their strong interpolymer interactions in aqueous solutions. Electrochemical and photophysical properties of conjugated polymers are extremely sensitive to interpolymer interactions. $^{6,7}$

Polymer gels which change their physical/chemical properties in response to external stimuli such as temperature, $\mathrm{pH}$, solvent composition or light irradiation have received much attention because of their potential uses in such things as sensors, drug-delivery devices and actuators. ${ }^{8-15}$ External stimuli affect the balance of interactions among polymer chains within the covalently cross-linked polymer network structures and these changes induce a volume change in polymer gels. In this study, we constructed covalently crosslinked conjugated polymer gels composed of water-soluble conjugated polymer chains and cross-linker and investigated their fluorescence and volume changes in response to various solvent compositions. Although the aggregation behavior of conjugated polymers has been widely investigated, crosslinked conjugated polymer gels are only rarely used. ${ }^{16,17}$ External stimuli affect the interpolymer interactions between conjugated polymers in a three-dimensional network structure and these changes influence conjugated polymers ground and excited states as well as gel volume.

\section{EXPERIMENTAL}

\section{General Procedures}

All reagents and solvents were purchased from Wako chemicals or TCI in analytical grade. All solvents were used after distillation. Adsorption column chromatography was performed using silica gel (Wakogel C-200, 200mesh). Analytical thin-layer chromatography was performed on commercial Merck plates coated with silica gel $60 \quad \mathrm{~F}_{254}$. Preparative HPLC was used on a JAI LC-908W system using $\mathrm{CHCl}_{3}$ as an eluent $(3.5 \mathrm{~mL} / \mathrm{min})$. Analytical gel permeation chromatography was used on a JASCO HPLC system (pump 1580, UV detector 1575, and refractive index detector 930) and a Showa Denko GPC KF-804L column (polystyrene standard $M=900-400000 \mathrm{~g} / \mathrm{mol})$ in THF as an eluent at $35^{\circ} \mathrm{C}$ (1.0 $\mathrm{mL} / \mathrm{min})$.

NMR spectra were recorded on a Bruker AVANCE 400 FT NMR spectrometer operating at $400.13 \mathrm{MHz}$ for ${ }^{1} \mathrm{H}$ and ${ }^{13} \mathrm{C}$, respectively, in $\mathrm{CDCl}_{3}$ or DMSO- $d_{6}$. Chemical shift were reported relative to internal TMS. IR and UV-vis spectra were recorded on a Shimazu IR Prestige-21 spectrometer with an ATR attachment and Multi Spec-1500. Fluorescence spectra were measured on a JASCO FP-750. Confocal laser scanning microscope and fluorescence microscope images were observed in OLYMPUS LEXT OLS-3000 and Nikon ECLIPSE E-600 POL microscopes, respectively. Fluorescence quantum yield was measured by a Hamamatsu Photonics absolute PL quantum yield measurement system C9920-01.

\begin{abstract}
Materials
Starting Material. 2,5-Diiodohydroquinone, 1,4-diiodo-2,5bis(3-bromopropoxy)benzene, and $\mathbf{2}$ were synthesized according to the reported methods. ${ }^{6,7}$

Synthesis of Dendritic Monomer 1. ${ }^{18-20}$ 1,4-Diiodo-2,5-bis(3bromopropoxy)benzene $(1.0 \mathrm{~g}, 1.66 \mathrm{mmol})$ was added to a stirred solution of $\mathrm{NaC}\left(\mathrm{CO}_{2} \mathrm{Et}\right)_{3}(970 \mathrm{mg}, 3.81 \mathrm{mmol})$ in DMFbenzene $(18 \mathrm{~mL}, 1: 1 \mathrm{v} / \mathrm{v})$ at $90^{\circ} \mathrm{C}$. After $24 \mathrm{~h}$, the solution was cooled and ethyl acetate was added. This solution was washed with water $(3 \times 100 \mathrm{~mL})$ and saturated aqueous $\mathrm{NaHCO}_{3}$ $(2 \times 100 \mathrm{~mL})$, and the collected organic phase was dried over
\end{abstract}

\footnotetext{
${ }^{1}$ Department of Functional Polymer Science, Faculty of Textile Science and Technology, Shinshu University, Ueda 386-8567, Japan

${ }^{2}$ Collaborative Innovation Center of Nanotech Fiber (nanoFIC), Shinshu University, Ueda 386-8567, Japan

*To whom correspondence should be addressed (Tel/Fax: +81-268-21-5499, E-mail: mkimura@ shinshu-u.ac.jp).
} 
anhydrous $\mathrm{MgSO}_{4}$. After evaporation, the crude residue was purified by column chromatography (silica gel, chloroform) and preparative HPLC to give a white solid in $62 \%$ yield. ${ }^{1} \mathrm{H} \mathrm{NMR}\left(\mathrm{CDCl}_{3}\right): \delta=7.25(\mathrm{~s}, 2 \mathrm{H}, \mathrm{Ar}-\boldsymbol{H}), 4.23(\mathrm{t}, J=7.2 \mathrm{~Hz}$, $\left.4 \mathrm{H},-\mathrm{CH}_{2} \mathrm{CH}_{3}\right), 3.89\left(\mathrm{t}, J=6.1 \mathrm{~Hz}, 4 \mathrm{H},-\mathrm{OCH}_{2}-\right), 2.31(\mathrm{t}$, $\left.J=8.0 \mathrm{~Hz}, 4 \mathrm{H},-\mathrm{OCH}_{2} \mathrm{CH}_{2}-\right), 2.04\left(\mathrm{~m}, 4 \mathrm{H},-\mathrm{CH}_{2} \mathrm{C}-\right), 1.13(\mathrm{t}$, $\left.J=7.0 \mathrm{~Hz}, 18 \mathrm{H},-\mathrm{CH}_{2} \mathrm{CH}_{3}\right) .{ }^{13} \mathrm{C} \mathrm{NMR}\left(\mathrm{CDCl}_{3}\right): \delta=167.0$, $152.8,122.9,86.3,70.1,65.3,62.2,30.2,29.9,24.9,14.0$. FTIR (ATR): $1727 \mathrm{~cm}^{-1}(\mathrm{C}=\mathrm{O})$.

Synthesis of Linear Polymer 3. ${ }^{21} \mathbf{1}(300 \mathrm{mg}, 0.33 \mathrm{mmol}), \mathbf{2}$ (160 mg, $0.33 \mathrm{mmol}), \mathrm{Pd}\left[\mathrm{P}(\mathrm{Ph})_{3}\right]_{4}(11.4 \mathrm{mg}, 9.9 \mu \mathrm{mol})$, and $\mathrm{CuI}$ $(2.1 \mathrm{mg}, 11.4 \mu \mathrm{mol})$ were combined in toluene $(1 \mathrm{~mL})$ and diisopropylamine ( $1 \mathrm{~mL}$ ) under $\mathrm{N}_{2}$. The reactants were heated at $70^{\circ} \mathrm{C}$ for $14 \mathrm{~h}$ to yield a noticeably viscous and fluorescent solution. After cooling, the material was added to rapidly stirred acetone $(200 \mathrm{~mL})$ and hexane $(100 \mathrm{~mL})$, and dried at $40{ }^{\circ} \mathrm{C}$ overnight to give a light yellow green solid in $54 \%$ yield. ${ }^{1} \mathrm{H}$ NMR $\left(\mathrm{CDCl}_{3}\right): \delta=7.5(\mathrm{br}, 2 \mathrm{H}, \mathrm{Ar} \boldsymbol{H}), 7.0(\mathrm{br}, 2 \mathrm{H}, \mathrm{Ar} \boldsymbol{H})$, 4.3 (br, $12 \mathrm{H}, \mathrm{CO}_{2} \mathrm{CH}_{2} \mathrm{CH}_{3}$ ), 4.1 (br, 8H, - $\left.\mathrm{OCH}_{2}-\right), 2.4$ (br, $4 \mathrm{H},-\mathrm{OCH}_{2} \mathrm{CH}_{2}-$ ), 2.1 (br, $2 \mathrm{H},-\mathrm{OCH}_{2} \mathrm{CH}_{2} \mathrm{CH}_{2}-$ ), 2.0 (br, $4 \mathrm{H}$, $\left.-\mathrm{OCH}_{2} \mathrm{CH}_{2} \mathrm{CH}_{2}-\right), 1.9$ (br, 4H, $\left.-\mathrm{CH}_{2} \mathrm{CH}_{2}-\right), 1.6$ (m, 4H, $-\mathrm{CH}_{2} \mathrm{CH}_{2}$ ), 1.4 (br., $18 \mathrm{H},-\mathrm{CH}_{2} \mathrm{CH}_{3}$ ), 1.1 (br., $72 \mathrm{H}$, $\left.-\mathrm{CH}_{2} \mathrm{CH}_{2}-\right), 0.9\left(\mathrm{t}, J=2.8 \mathrm{~Hz}, 6 \mathrm{H},-\mathrm{CH}_{2} \mathrm{CH}_{3}\right) .{ }^{13} \mathrm{C} \mathrm{NMR}$ $\left(\mathrm{CDCl}_{3}\right): \delta=166.9,153.3,153.0,144.8,137.1,125.2,120.5$, 113.0, 111.0, 109.5, 100.1, 91.8, 86.3, 70.2, 69.7, 65.3, 62.0, 31.9, 30.3, 29.7, 29.4, 26.0, 25.0, 24.0, 22.6, 19.2, 14.1, 13.9. FT-IR (ATR): $1734 \mathrm{~cm}^{-1}(\mathrm{C}=\mathrm{O})$. GPC (polystyrene standards, THF): $M_{\mathrm{n}}=3.7 \times 10^{4} \mathrm{~g} / \mathrm{mol}(\mathrm{PDI}=2.3)$.

Amidation with Tris 4. ${ }^{18-20}$ Polymer $3(80 \mathrm{mg}, 0.21 \mathrm{mmol})$ and Tris(hydroxymethyl)aminomethane (Tris) (210 mg, $1.70 \mathrm{mmol})$ were dissolved in dry DMSO $(20 \mathrm{~mL})$ and stirred over anhydrous $\mathrm{K}_{2} \mathrm{CO}_{3}$ (470 mg, $3.42 \mathrm{mmol}$ ) for $7 \mathrm{~d}$ at $25^{\circ} \mathrm{C}$. The mixture was filtered and evaporated in vacuo. The 4 were obtained via dissolution of the oily residue in water and precipitation by the slow addition of acetone to give a yellow solid (98\%). ${ }^{1} \mathrm{H}$ NMR (DMSO- $d_{6}$ ): $\delta=7.6$ (br, 4H, ArH ), 6.5 (br, 6H, -NH), 4.5 (br, 6H, -NHCH $\left.{ }_{2} \mathrm{OH}\right), 4.1$ (br, 4H, -OCH ${ }_{2}^{-}$), 2.6-2.3 (br, 6H, $-\mathrm{OCH}_{2} \mathrm{CH}_{2}-$ ). $\left.{ }^{13} \mathrm{C} \mathrm{NMR} \mathrm{(DMSO-} d_{6}\right): \delta=$ $171.2,167.2,156.8,150.2,148.3,134.0,127.2,120.2,119.4$, 114.6, 113.1, 111.9, 107.7, 99.3, 98.0, 94.3, 81.0, 72.6, 70.7, 68.2, 67.6, 65.3, 61.0, 53.3, 44.4, 32.0, 29.7, 29.5, 29.1, 28.9, 26.6, 24.9, 20.3, 18.4, 14.3. FT-IR (ATR): $3422(-\mathrm{OH})$, $1654 \mathrm{~cm}^{-1}$ (-CONH-).

Synthesis of Cross-linker 5. ${ }^{6} \quad \mathrm{~K}_{2} \mathrm{CO}_{3}(3.08 \mathrm{~g}, 20 \mathrm{mmol})$ and 1-dodecyl bromide $(1.14 \mathrm{~mL}, 4.77 \mathrm{mmol})$ were added to a solution of 2,4,6-triiodophenol $(1.30 \mathrm{~g}, 3.18 \mathrm{mmol})$ in acetone $(80 \mathrm{~mL})$ and the reaction mixture was refluxed for $2 \mathrm{~d}$. After evaporation of solvent, a brown residue was recrystallized from methanol to yield a white crystal 1,3,5-triiodo-2-dodecyloxybenzene in $83 \%$ yield. ${ }^{1} \mathrm{H} \mathrm{NMR}\left(\mathrm{CDCl}_{3}\right): \delta=7.25(\mathrm{~s}, 2 \mathrm{H}, \mathrm{Ar}-$ $\boldsymbol{H}), 3.95\left(\mathrm{t}, J=6.4 \mathrm{~Hz}, 2 \mathrm{H},-\mathrm{OCH}_{2} \mathrm{CH}_{2}\right), 1.93(\mathrm{t}, J=7.2 \mathrm{~Hz}$, $\left.2 \mathrm{H},-\mathrm{OCH}_{2} \boldsymbol{C H}_{2}\right) 1.36\left(\mathrm{~m}, 18 \mathrm{H},-\mathrm{CH}_{2}-\right) 0.89(\mathrm{t}, J=6.8 \mathrm{~Hz}, 3 \mathrm{H}$, $\left.-\mathrm{CH}_{3}\right)$. FT-IR (ATR): $2915 \mathrm{~cm}^{-1}\left(-\mathrm{CH}_{2}-\right) .{ }^{13} \mathrm{C}$ NMR (DMSO$\left.d_{6}\right): \delta=158.3,147.2,92.1,91.7,88.8,73.6,31.9,29.9,29.6$, 25.9, 22.7, 14.1 .

1,3,5-Triiodo-2-dodecyloxybenzene $(550 \mathrm{mg}, 0.91 \mathrm{mmol})$,
$\mathrm{CuI}(2.1 \mathrm{mg}, 11.4 \mu \mathrm{mol})$ and $\mathrm{Pd}\left[\mathrm{P}(\mathrm{Ph})_{3}\right]_{4} \mathrm{Cl}_{2} \quad(60 \mathrm{mg}, 9.10$ $\mu \mathrm{mol})$ were dissolved in diisopropylamine $(20 \mathrm{~mL})$ at room temperature. Trimethylsilylacetylene $(1.01 \mathrm{~mL}, 7.28 \mathrm{mmol})$ was added to the mixture and the mixture was refluxed for $2 \mathrm{~h}$. The crude product was purified by column chromatography (silica gel, $\mathrm{CH}_{2} \mathrm{Cl}_{2} /$ hexane $7: 1 \mathrm{v} / \mathrm{v}$ ) to give an oily $1,3,5$ tris(trimethylsilylethynyl)-2-dodecyloxybenzene in $73 \%$ yield. ${ }^{1} \mathrm{H} \mathrm{NMR}\left(\mathrm{CDCl}_{3}\right) \delta=7.25(\mathrm{~s}, 2 \mathrm{H}, \mathrm{Ar}-\boldsymbol{H}), 4.23(\mathrm{t}, J=6.4 \mathrm{~Hz}$, $\left.2 \mathrm{H},-\mathrm{OCH}_{2} \mathrm{CH}_{2}\right), 1.82\left(\mathrm{t}, \mathrm{J}=7.2 \mathrm{~Hz}, 2 \mathrm{H},-\mathrm{OCH}_{2} \boldsymbol{C H}_{2}\right), 1.54$ $\left(\mathrm{m}, 18 \mathrm{H},-\boldsymbol{C H}_{2^{-}}\right), 0.88\left(\mathrm{t}, J=6.8 \mathrm{~Hz}, 3 \mathrm{H},-\boldsymbol{C H}_{3}\right), 0.23(\mathrm{~m}$, $\left.27 \mathrm{H},-\mathrm{Si}\left(\mathrm{CH}_{3}\right)_{3}\right) .{ }^{13} \mathrm{C}$ NMR (DMSO- $\left.d_{6}\right): \delta=158.5,140.8$, $112.4,110.0,106.0,105.3,99.0,98.3,73.6,31.9,29.9,29.6$, 25.9, 22.7, 14.3. FT-IR (ATR): $2924\left(-\mathrm{CH}_{2}-\right), 2158 \mathrm{~cm}^{-1}$ $(-\mathrm{C} \equiv \mathrm{C}-)$.

Methanol $(5 \mathrm{~mL})$ and aqueous $\mathrm{KOH}(2.0 \mathrm{~mL}, 20 \mathrm{wt} \%)$ were added to a rapidly stirred solution of 1,3,5-tris(trimethylsilylethynyl)-2-dodecyloxybenzene $(140 \mathrm{mg}, 0.27 \mathrm{mmol})$ in THF $(5 \mathrm{~mL})$ at room temperature for $5 \mathrm{~h}$. Diethyl ether was added and washed with water, and the collected organic phase was dried over anhydrous $\mathrm{MgSO}_{4}$. After evaporation, the crude residue was purified by column chromatography (silica gel, $\mathrm{CH}_{2} \mathrm{Cl}_{2} /$ hexane $\left.3: 1 \mathrm{v} / \mathrm{v}\right)$ in $67 \%$ yield. ${ }^{1} \mathrm{H} \mathrm{NMR}\left(\mathrm{CDCl}_{3}\right): \delta=$ 7.54 (s, 2H, Ar- $\boldsymbol{H}), 4.26$ (t, $\left.J=6.8 \mathrm{~Hz}, 2 \mathrm{H},-\mathrm{OCH}_{2} \mathrm{CH}_{2}\right), 3.26$ $(\mathrm{s}, 3 \mathrm{H},-\mathrm{C} \equiv \mathrm{CH}), 1.83\left(\mathrm{t}, J=7.2 \mathrm{~Hz}, 2 \mathrm{H},-\mathrm{OCH}_{2} \boldsymbol{C H}_{2}\right), 1.54$ $\left(\mathrm{m}, 18 \mathrm{H},-\boldsymbol{C H}_{2}-\right), 0.88\left(\mathrm{t}, J=6.8 \mathrm{~Hz}, 3 \mathrm{H},-\boldsymbol{C H}_{3}\right) .{ }^{13} \mathrm{C} \mathrm{NMR}$ $\left(\mathrm{CDCl}_{3}\right): \delta=169.9,138.2,117.3,117.0,82.3,81.4,74.7,31.9$, 30.2, 29.9, 29.7, 25.9, 22.7, 14.1. FT-IR (ATR): $3280 \mathrm{~cm}^{-1}$ $(-\mathrm{C} \equiv \mathrm{CH})$.

Preparation of Gel Particle 6. ${ }^{16,17} \mathbf{1}(116 \mathrm{mg}, 0.234 \mathrm{mmol})$, 2 (270 mg, $0.301 \mathrm{mmol}), 5(10 \mathrm{mg}, 0.030 \mathrm{mmol}), \mathrm{Pd}\left[\mathrm{P}(\mathrm{Ph})_{3}\right]_{4}$ (20 mg, $0.02 \mathrm{mmol})$, and $\mathrm{CuI}(3.2 \mathrm{mg}, 0.01 \mathrm{mmol})$ were combined in a mixture of toluene $(1 \mathrm{~mL})$ and diisopropylamine (1 mL) under $\mathrm{N}_{2}$. The solution was stirred for $60 \mathrm{~s}$, an aqueous solution $(60 \mathrm{~mL})$ of sodium lauryl sulfate $(0.8 \mathrm{~g})$ was added, and the mixture was heated to $80^{\circ} \mathrm{C}$ and stirred vigorously for $2 \mathrm{~d}$. The reaction mixture, which had turned into an orange suspension, was cooled to room temperature and the solvents were evaporated in vacuo. Toluene $(100 \mathrm{~mL})$ was added, and the mixture was ultrasonicated for $1 \mathrm{~h}$. The solid content of the resulting suspension was separated by centrifugation and the supernatant solution was discarded. This procedure was repeated with toluene/methanol mixture $(3: 1,1: 1$, and $1: 3$ $\mathrm{v} / \mathrm{v}$ ), methanol, and twice with toluene. The product was collected and dried overnight in vacuo to yield a yellow solid (90\%). FT-IR (ATR): $1732 \mathrm{~cm}^{-1}(\mathrm{C}=\mathrm{O})$.

Amidation with Tris $7 .^{18-20} \mathbf{6}(100 \mathrm{mg}, 0.07 \mathrm{mmol})$ and Tris $(210 \mathrm{mg} 1.70 \mathrm{mmol})$ were added to dry DMSO $(20 \mathrm{~mL})$ and stirred over anhydrous $\mathrm{K}_{2} \mathrm{CO}_{3}(500 \mathrm{mg}, 3.62 \mathrm{mmol})$ at room temperature for 1 week. After filtration, yellow solid was washed with water and methanol to give a yellow solid (97\%). FT-IR (ATR): 3305 (-OH), $1651 \mathrm{~cm}^{-1}$ (-CONH-).

\section{RESULT AND DISCUSSION}

We designed and synthesized poly( $p$-phenylene ethynylene)s (PPEs) having hydroxyl and amide groups as a side 


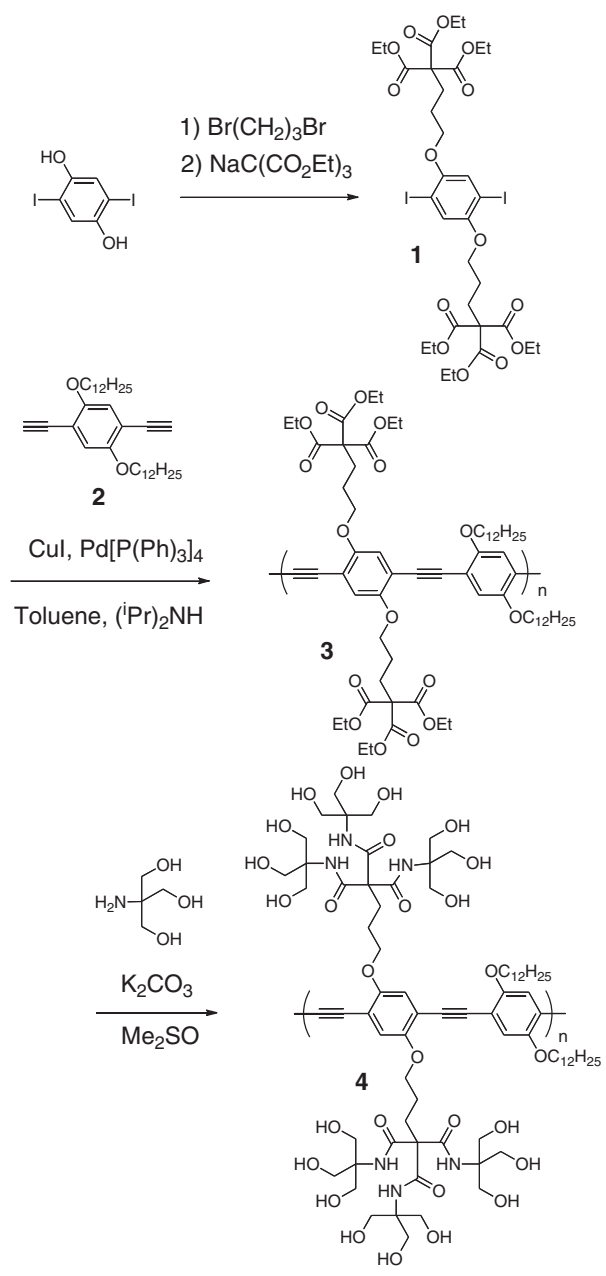

Scheme 1.

chain of conjugated polymers (Scheme 1) ${ }^{18-20}$ Hexaethyl ester 1 was prepared using 2,5-diiodohydroquinone in two steps. A Pd-catalyzed Sonogashira cross-coupling reaction between $\mathbf{1}$ and 1,4-diethynyl-2,5-bis-(dodecyloxy)benzene $\mathbf{2}$ in the presence of $\mathrm{CuI}$ yielded the desired linear polymer 3 . $^{21}$ Polymer 3 is a yellow solid with $M_{\mathrm{n}}=3.7 \times 10^{4} \mathrm{~g} / \mathrm{mol}$ and PDI $=2.3$ as analyzed by gel permeation chromatography (polystyrene standards, THF as an eluent). The target amphiphilic PPE 4 was afforded by the adaptation of Newkome's synthesis of arborols. ${ }^{19}$ The ester groups in $\mathbf{3}$ were converted to the desired 4 using amidation with tris(hydroxymethyl)aminomethane (Tris) in dry $\mathrm{Me}_{2} \mathrm{SO}$ and in the presence of $\mathrm{K}_{2} \mathrm{CO}_{3}$. After the conversion, the resulting polymer was purified by the precipitation from acetone precipitation to remove excess Tris. Transformation from $\mathbf{3}$ to $\mathbf{4}$ was verified by FT-IR and ${ }^{13} \mathrm{C}$ NMR spectra. The FT-IR spectrum of $\mathbf{4}$ exhibited a new amide carbonyl stretch band (ca. $1650 \mathrm{~cm}^{-1}$ ) and a broad $\mathrm{OH}$ stretch band at $3330 \mathrm{~cm}^{-1}$. Moreover, a downfield shift of the $\mathrm{C}=\mathrm{O}$ groups and disappearance of the peaks of the ester moieties in the ${ }^{13} \mathrm{C}$ NMR spectrum indicated almost complete amidation in the side chains of $\mathbf{3}$ with Tris. Although the parent polymer $\mathbf{3}$ is very soluble in many organic solvents such as $\mathrm{CHCl}_{3}, \mathrm{CH}_{2} \mathrm{Cl}_{2}$, and THF, 4 having an alternative hydrophilic-
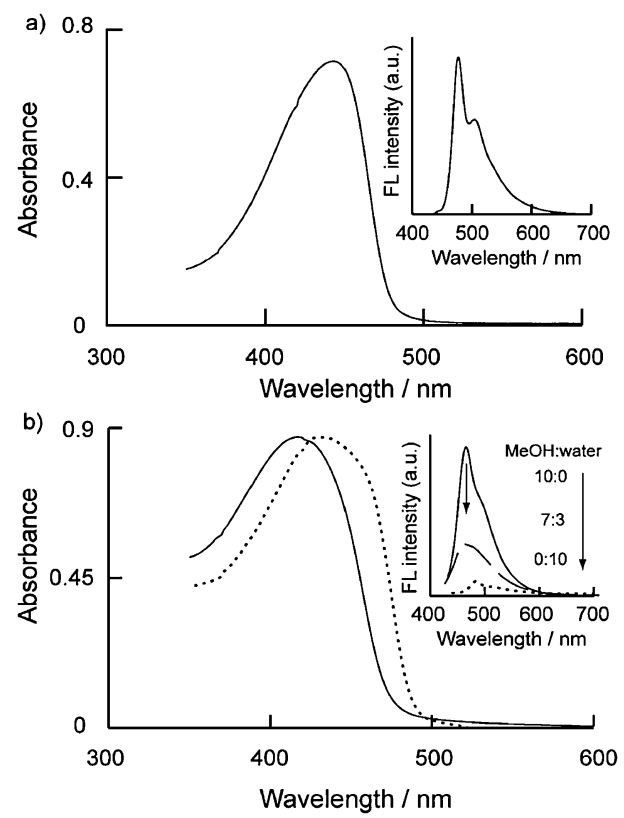

Figure 1. (a) Absorption spectrum of 3 in toluene. The inset shows the fluorescence spectrum of $\mathbf{3}$ in toluene. (b) Absorption spectra of $\mathbf{4}$ in methanol (solid line) and water (dotted line). The inset shows the fluorescence spectral change of $\mathbf{4}$ in response to solvent composition.

hydrophobic side chain pattern is completely soluble in water and alcohols. This solubility change indicates that the hydrophobic PPEs backbone was wrapped with water-soluble branched segments.

Polymer 3 displays a broad absorption band in the visible region around $443 \mathrm{~nm}$ in toluene (Figure 1a). Appearance of this new band shows an extended $\pi$-electronic conjugation along the backbones caused by the polymerization of $\mathbf{1}$ and $2 .^{22}$ The fluorescence peak of 3 in toluene appeared at $477 \mathrm{~nm}$ with a vibronic band shoulder at $502 \mathrm{~nm} .{ }^{23}$ Absorption and fluorescence spectra of $\mathbf{3}$ are almost identical to the previously reported spectra of structurally analogous PPEs polymers having alkyloxy-solubilizing groups, ${ }^{6}$ indicating that the electronic property of $\mathbf{3}$ was predominantly governed by the rigid-rod and highly conjugated polymer backbone and was influenced very littele by the nature of the attached side chains. Figure $1 \mathrm{~b}$ shows the absorption and fluorescence spectra of $\mathbf{4}$ in methanol. Absorption and emission peaks of $\mathbf{4}$ in methanol show an obvious blue-shift in comparison with that of $\mathbf{3}$ in toluene. ${ }^{23}$ Emission quantum yield $(\phi)$ was as $\phi=0.68$ for $\mathbf{3}$ in toluene and 0.43 for 4 in methanol. The optical properties of PPEs have been widely investigated because of their unique response to environmental variation through the conformational change of individual polymers and interpolymer aggregation. The relative free rotation of alkyne-aryl single bond allows the formation of planar and non-planar conformations of a single PPEs backbone. ${ }^{24}$ The observed blue-shifts in the absorption and fluorescence spectra of 4 suggest that the introduction of sterically bulky arborol side chains into the PPEs backbone leads to a main chain conformational change caused by an increase in twist angle in alkyne-aryl single bond 


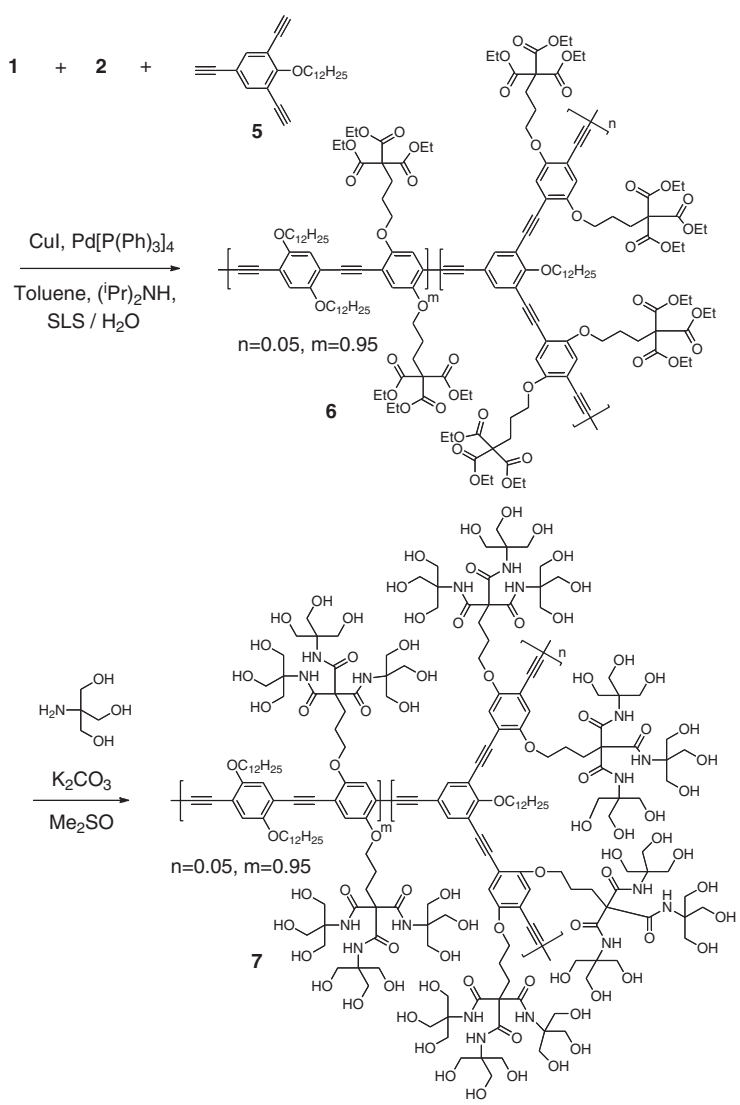

Scheme 2.

thereby reducing the effective conjugation length. ${ }^{25}$ When 4 in methanol was added to water, the absorption peak red-shifted from $416 \mathrm{~nm}$ to $434 \mathrm{~nm}$ as shown in Figure 1b. This shift is believed to occur because $\pi$-stacking among conjugated PPEs chains in the aggregates induces the arylene-ethynylene units to adopt planar conformation. ${ }^{24}$ The planar conformation of PPE chains results in the increase in $\pi$-conjugation length. Emission at $466 \mathrm{~nm}$ is dramatically quenched by the addition of water and the emission quantum yield $(\phi=0.04)$ for 4 in water, which indicates that hydrophobic PPEs backbones are in an aggregated form through interpolymer $\pi-\pi$ interactions in aqueous solutions. ${ }^{3}$

Weder and coworkers found that the cross-coupling polymerizations within the oil-in-water emulsion in the presence of an auxiliary surfactant produced micrometer-sized spherical conjugated polymer gels. ${ }^{16} \mathrm{We}$ prepared the cross-linked spherical PPE gels using the Pd-catalyzed Sonogashira cross coupling reaction with 1, 2 and 2-dodecyloxy-1,3,5-triethynylbenzene $\mathbf{5}$ in aqueous emulsion (Scheme 2). Compound $\mathbf{5}$ having three ethynyl units was used as a cross-linker for the formation of conjugated polymer networks. The conjugated gel 6 was prepared under a nitrogen atmosphere by mixing 1, 2, and 5 in toluene and $(i-\mathrm{Pr})_{2} \mathrm{NH}$ with $\mathrm{CuI}$ and $\mathrm{Pd}\left[\mathrm{P}(\mathrm{Ph})_{3}\right]_{4}$ as catalysts for the Sonogashira cross-coupling reaction. Sodium lauryl sulfate (SLS) aqueous solution was added and the mixture was stirred vigorously at $80^{\circ} \mathrm{C}$ for $48 \mathrm{~h}$. The solution turned to a highly fluorescent yellow-orange, indicating that the

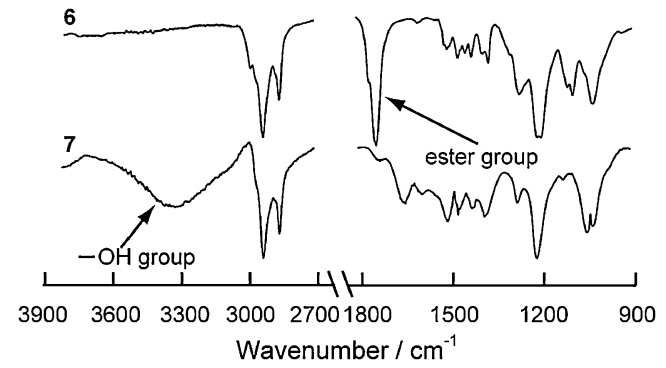

Figure 2. FT-IR spectra of conjugated PPE gels 6 (top) and 7 (bottom).
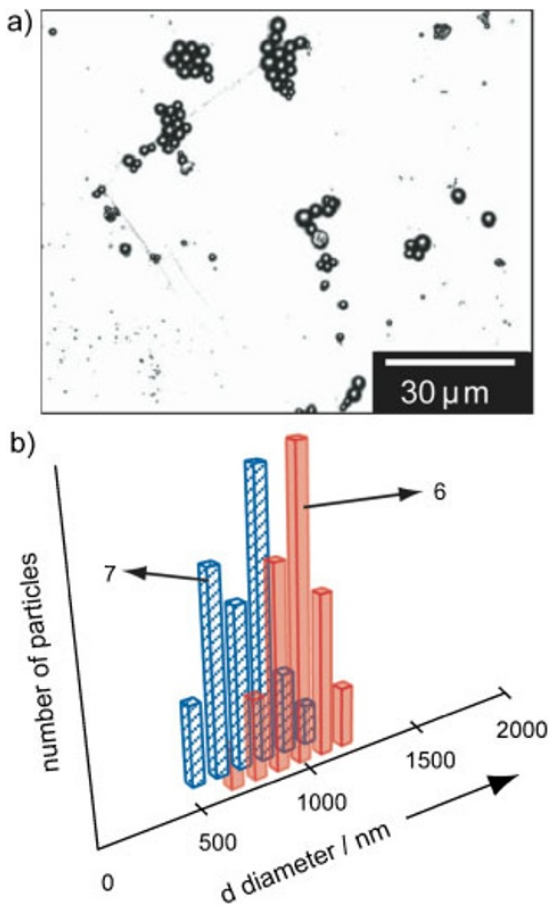

Figure 3. (a) CLSM image of 7 swelled in water. (b) Size distributions of 6 swelled in toluene and 7 swelled in water.

cross-coupling reaction proceeds smoothly in emulsion. The formed conjugated gel $\mathbf{6}$ was collected and washed with toluene, methanol and water to remove unreacted compounds, catalysts, and SLS. To investigate the influence of the crosslinking ratio, polymerizations were carried out in two molar ratios of 9:7:1 and 9:7.5:0.5 of monomers 1, 2, and 5. Although the yield for the polymerization in the ratio of 9:7:1 was above $90 \%$, the yield in the ratio of 9:7.5:0.5 was only $16 \%$. In this context, a molar ratio of 9:7:1 of $\mathbf{1 , 2}$, and $\mathbf{5}$ was chosen for the preparation of conjugated gels. Conjugated gel $\mathbf{6}$ was treated with Tris for one week, after which the precipitate was collected and washed with water and methanol to give 7. FT-IR spectra of the resulted conjugated gels 6 and 7 were consistent with the expected molecular structures (Figure 2). The shape and diameter of gels were measured under a confocal laser scanning microscope (CLSM). The microscopy images of dried gels 6 and 7 revealed spherical particles with average diameters of 0.27 and $0.38 \mu \mathrm{m}$, respectively. Figure 3 shows a CLSM image of water-swollen conjugated gel 7 and size distributions 


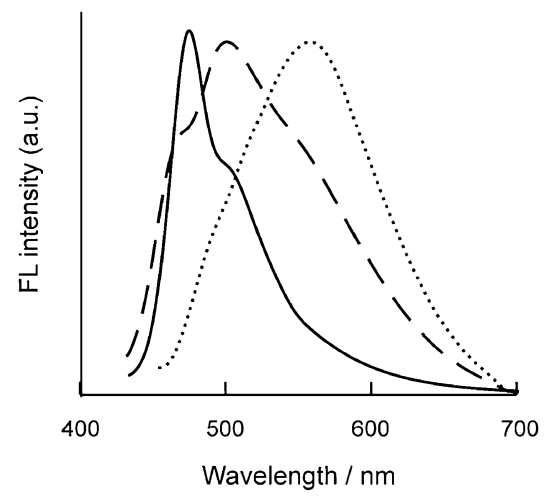

Figure 4. Fluorescence spectra of 6 swelled in toluene (solid line) and 7 swelled in methanol (dashed line) and water (dotted line).

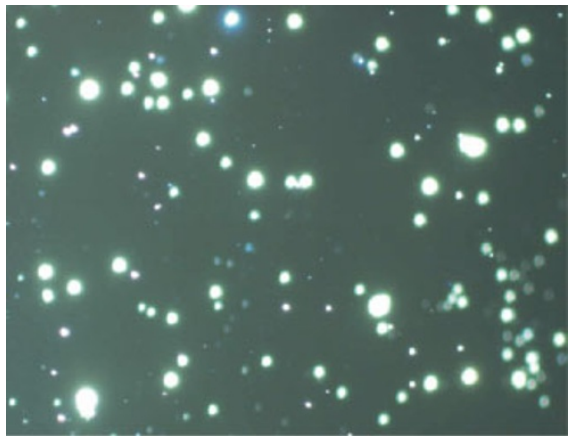

Figure 5. Fluorescence microscope image of 7 swelled in water at irradiation by UV light in the range of $365-375 \mathrm{~nm}$.

of toluene-swollen gel 6 and water-swollen gel 7. When 6 was immersed in toluene, the spherical particles swelled and the size distributions of $\mathbf{6}$ were relatively narrow with an average diameter of $1.00 \mu \mathrm{m}$ (50 times volume change).

The fluorescence peak of the toluene-swollen 6 appeared at $478 \mathrm{~nm}$ with a vibronic band at $500 \mathrm{~nm}$, which is very similar to that of reference linear polymer 3 (Figure 4). This suggests that the electronic properties of PPEs units in gels are almost the same as those of linear PPE polymers and that PPE chains are independent from each other within the swollen gels. Gel 7 having hydrophilic side chains could be swelled in methanol and water. The fluorescence spectrum of methanol-swollen gel 7 shows a broad band at $502 \mathrm{~nm}$ having a shoulder peak at $480 \mathrm{~nm}$. In contrast, the fluorescence band of water-swollen gel 7 is red-shifted $50 \mathrm{~nm}$ from the fluorescence maximum of methanol-swollen gel.

Water-swollen gel 7 emitted a blue-green light under irradiation from UV light in a range of 365-375 nm observed under a fluorescence microscope (Figure 5). This broad fluorescence band occurs exclusively because of an excimerlike excited state arising from interchain $\pi-\pi$ stacking in the aggregate. $^{23}$ The fluorescence changes observed in 7 in methanol and water suggest that the polymer chain in gel exists in an aggregated state in water and in a relatively less aggregated state in methanol. Aggregation of PPEs chains within the three-dimensional network structure was induced by

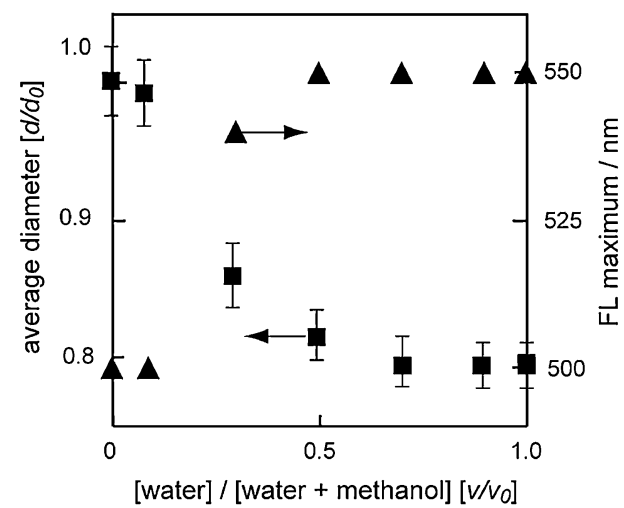

Figure 6. Changes in gel volume $(\boldsymbol{\square})$ and fluorescence maximum $(\boldsymbol{\Delta})$ of $\mathbf{7}$ in methanol $\left(d_{0}\right)$, methanol/water $(9: 1 \mathrm{v} / \mathrm{v}, 7: 3 \mathrm{v} / \mathrm{v}, 5: 5 \mathrm{v} / \mathrm{v}, 3: 7$ $\mathrm{v} / \mathrm{v}$, and 1:9 v/v) $(d)$.

hydrophobic and $\pi-\pi$ interactions between the polymer chains. These interchain interactions also affect the gel volume. When 7 was immersed in methanol or water for $48 \mathrm{~h}$, an average equilibrium particle diameter of 7 was measured under a CLSM. The average diameter of particles in methanol $(1.13 \mu \mathrm{m})$ was greater than that in water $(0.90 \mu \mathrm{m})$ and the size distribution of water-swollen gel 7 was comparable to that of toluene-swollen gel $\mathbf{6}$ as shown in Figure $3 b$.

Figure 6 shows the dependence of diameter and fluorescence maximum of 7 on water ratio in mixed solvent. The addition of water resulted in the shrinking of gel volume as well as the shifting of fluorescence peak. These changes also indicate the degree of aggregation among PPEs chains within the three-dimensional network structure.

\section{CONCLUSION}

In conclusion, we have succeeded in synthesizing spherical conjugated gels using the $\mathrm{Pd}$-catalyzed cross-coupling reaction in emulsion and shown that the side chains of PPEs backbone in gels can be converted to hydrophilic Tris. The synthesized 7 swelled in polar solvents such as water and alcohols and emitted a blue-green fluorescence. The aggregation of PPEs backbones within the three-dimensional network structure affected the fluorescence spectra and the gel volume. Molecular recognition events within the three-dimensional network structure can be analyzed by combining two different output signals for fluorescence and volume changes. Further experiments focusing on the sensing abilities of a conjugated gel that interferes with the interchain interaction among conjugated backbones in response to the presence of the target molecule are currently underway.

Acknowledgment. This work was partially supported by Global COE Program for "International Center of Excellence on Fiber Engineering" and for "Innovation Creative Center for Advanced Interdisciplinary Research Areas" in Special Coordination Funds for Promoting Science and Technology from the Ministry of Education, Culture, Sports, Science, and Technology, Japan. 
Received: October 5, 2008

Accepted: October 29, 2008

Published: December 11, 2008

\section{REFERENCES}

1. "Handbook of Conducting Polymers," 3rd ed., T. A. Skothem and J. R. Reynolds, Ed., CRC Press, Boca Raton, London, New York, 2007.

2. C. Tan, M. R. Pinto, and K. S. Schanze, Chem. Commun., 446 (2002).

3. I.-K. Kim, A. Dunkhorst, J. Gilbert, and U. H. F. Bunz, Macromolecules 38, 4560 (2005).

4. C. Li, M. Numata, M. Takeuchi, and S. Shinkai, Angew. Chem., Int. Ed., 44, 6371 (2005).

5. J. H. Wosnick, C. M. Mello, and T. M. Swager, J. Am. Chem. Soc., 127, 3400 (2005).

6. T. McQuade, A. E. Pullen, and T. M. Swager, Chem. Rev., 100, 2537 (2000) and references therein.

7. J. Kim and T. M. Swager, Nature, 411, 1030 (2001).

8. A. Suzuki and T. Tanaka, Nature, 346, 345 (1990).

9. E. Kokufata, Y.-Q. Zhang, and T. Tanaka, Nature, 351, 302 (1991).

10. E. S. Matsuo and T. Tanaka, Nature, 358, 482 (1992).

11. M. Annaka and T. Tanaka, Nature, 351, 302 (1991).

12. Y.-Q. Zhang, T. Tanaka, and M. Shibayama, Nature, 360, 142 (1992).
13. K. Kataoka, H. Miyazaki, M. Bunya, T. Okano, and Y. Sakurai, J. Am. Chem. Soc., 120, 12694 (1998).

14. A. Mamada, T. Tanaka, D. Kungwatchakun, and M. Irie, Macromolecules, 23, 1517 (1990).

15. Y. Osada, H. Okuzaki, and H. Hori, Nature, 355, 242 (1992).

16. E. Hittinger, A. Kokil, and C. Weder, Angew. Chem., Int. Ed., 43, 1808 (2004).

17. C. Weder, Chem. Commun., 5378 (2005).

18. G. R. Newkome, G. R. Baker, S. Arai, M. J. Saunders, P. S. Russo, K. J. Theriot, C. N. Moorefield, L. E. Rogers, J. E. Miller, T. R. Lieux, M. E. Murray, B. Phillips, and L. Pascal, J. Am. Chem. Soc., 112, 8458 (1990)

19. G. R. Newkome, X. Lin, C. Yaxiong, and G. H. Escamilla, J. Org. Chem., 58, 3123 (1993).

20. K. Kuroda and T. M. Swager, Chem. Commun., 26 (2003).

21. K. Sonogashira, Y. Tohda, and N. Hagihara, Tetrahedron Lett., 4467 (1975).

22. M. Wagner and O. Nuyken, Macromolecules, 36, 6716 (2003).

23. Q.-L. Fan, Y. Zhou, X.-M. Lu, X.-Y. Hou, and W. Huang, Macromolecules, 38, 2927 (2005).

24. M. R. Pinto, B. M. Kristal, and K. S. Schanze, Langmuir, 19, 6523 (2003).

25. M. Levitus, K. Schmieder, H. Ricks, K. D. Shimizu, U. H. F. Bunz, and M. A. Garcia-Garibay, J. Am. Chem. Soc., 123, 4259 (2001). 